TITLE:

\title{
A NEW ONISCOPSIS SPECIES (COPEPODA, HARPACTICOIDA) FOUND ON THE SANDY BEACH OF MUKAISHIMA ISLAND, THE INLAND SEA OF JAPAN
}

\author{
$\operatorname{AUTHOR}(\mathrm{S}):$ \\ Kitazima, Yoshiroh
}

\section{CITATION:}

Kitazima, Yoshiroh. A NEW ONISCOPSIS SPECIES (COPEPODA, HARPACTICOIDA) FOUND ON THE SANDY BEACH OF MUKAISHIMA ISLAND, THE INLAND SEA OF JAPAN.

PUBLICATIONS OF THE SETO MARINE BIOLOGICAL LABORATORY 1983, 27(4-6): 269-280

ISSUE DATE:

1983-01-31

URL:

http://hdl.handle.net/2433/176053

RIGHT: 


\title{
A NEW ONISCOPSIS SPECIES (COPEPODA, HARPACTICOIDA) FOUND ON THE SANDY BEACH OF MUKAISHIMA ISLAND, THE INLAND SEA OF JAPAN ${ }^{1)}$
}

\author{
YosHIROH KITAZIMA \\ Mukaishima Marine Biological Station, Hiroshima University, \\ Onomichi P.O., Hiroshima 722, Japan \\ With Text-figures $1-8$ and Table 1
}

In this paper, a new species of the genus Oniscopsis Chappuis, 1954 (Copepoda, Harpacticoida, Tetragonicipitidae: see Becker and Kunz, 1981) is described on the basis of some male and female specimens from the interstices of beach sand in Mukaishima Island, the Inland Sea of Japan. The genus Oniscopsis is, at present, composed of two species: $O$. pauliani Chappuis, 1954 and $O$. robinsoni Chappuis \& Delamare Deboutteville, 1956. This is the first record of this genus from Japan.

The sampling station is situated midway between M.H.W.S. and M.H.W.N. on the beach (about 3.1 meters above the datum line), where the mean grain size is approximately $1.8 \mathrm{~mm}$ in diameter. The material was obtained from sand samples by means of the so-called decanting-sieving method. Dissected somites and appendages were mounted on slides using Sasa's gum-chloral medium. Slide preparations used for the description are indicated by numbers in parentheses. The surface structure of the integument was examined with a scanning electron microscope, JSM-25 (Japanese Electron Optics Lab.). All specimens examined are deposited in the Mukaishima Marine Biological Station, Hiroshima University.

Before going further, I would like to express my sincere thanks to Professor Akihiko Inaba of the Mukaishima Marine Biological Station, Hiroshima University, for his support and guidance to the present study. Sincere thanks are also due to Professor F.E. Round of the Department of Botany, University of Bristol, who read the manuscript with good grace. I am also grateful to Dr. Tatsunori Itô of the Seto Marine Biological Laboratory, Kyoto University, for giving beneficial advices.

\section{Oniscopsis inabai n. sp.}

Female. Body (Fig. 1, 1-2) somewhat depressed dorso-ventrally, about $0.64 \mathrm{~mm}$ long, furcal setae excluded, and about $0.17 \mathrm{~mm}$ in greatest width measured at the cephalothoracic somite. Semitransparent, tinged with light greenish brown. A

1) Contribution from the Mukaishima Marine Biological Station, No. 198.

Publ. Seto Mar. Biol. Lab., XXVII (4/6), 269-280, 1983.

(Article 14) 


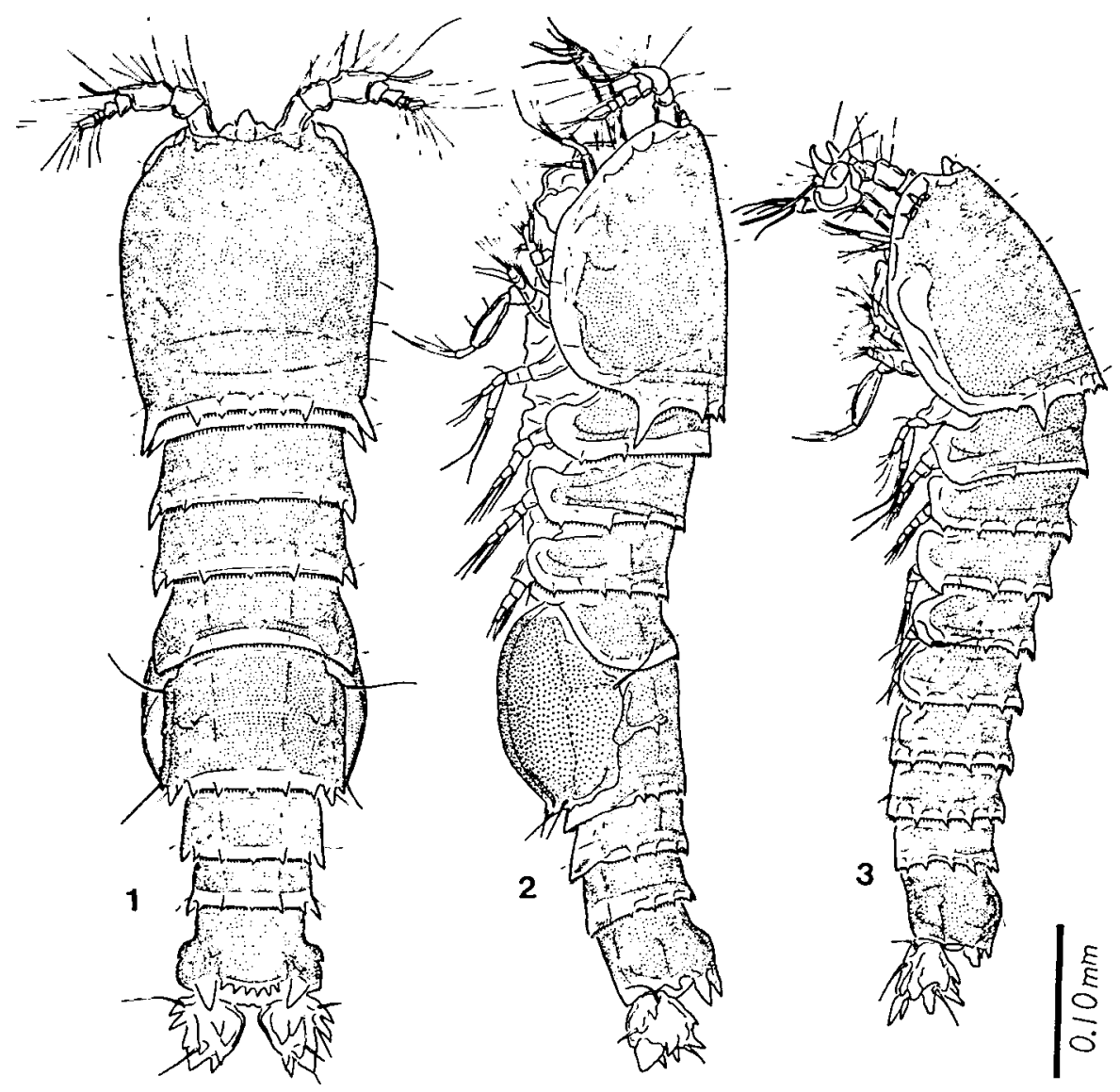

Fig. 1. Oniscopsis inabai n. sp. Female (holotype). 1. habitus, dorsal; 2. ditto, lateral. Male (allotype). 3. habitus, lateral.

nauplian eye invisible. Dorsal surface of the integument strikingly punctured throughout the body (Fig. 2, 1), except for the furcal ramus. Dorsal hind edge of each somite except for anal somite finely serrated and ornamented with several spaced projections; two of the projections on cephalothorax, each located dorsolaterally, well developed, rather unguiform. Genital double-somite (Fig. 3, 1-3) large, with only short dorso-lateral traces of subdivision; genital area as shown in Fig. 4, 1. Leg 6 (Fig. 3, 3) represented by a small rectangular segment with three bare setae, of which the outermost is much longer than the others. Antepenultimate somite is similar to the preceding somite in ornamentation of the hind rim as shown in Fig. 3. Penultimate somite serrated along the ventral hind edge, ornamented with many hairs on the ventro-lateral face near the hind edge. Anal somite forming a wide posterior part which swells out laterally and dorsally; two large dentiform projections at the dorso-lateral hind edges on both sides of the anal operculum which is fringed with six small dentiform projections. Furcal ramus a little shorter than wide, with six (?) projections, all of which are covered with numerous minute spinules; 


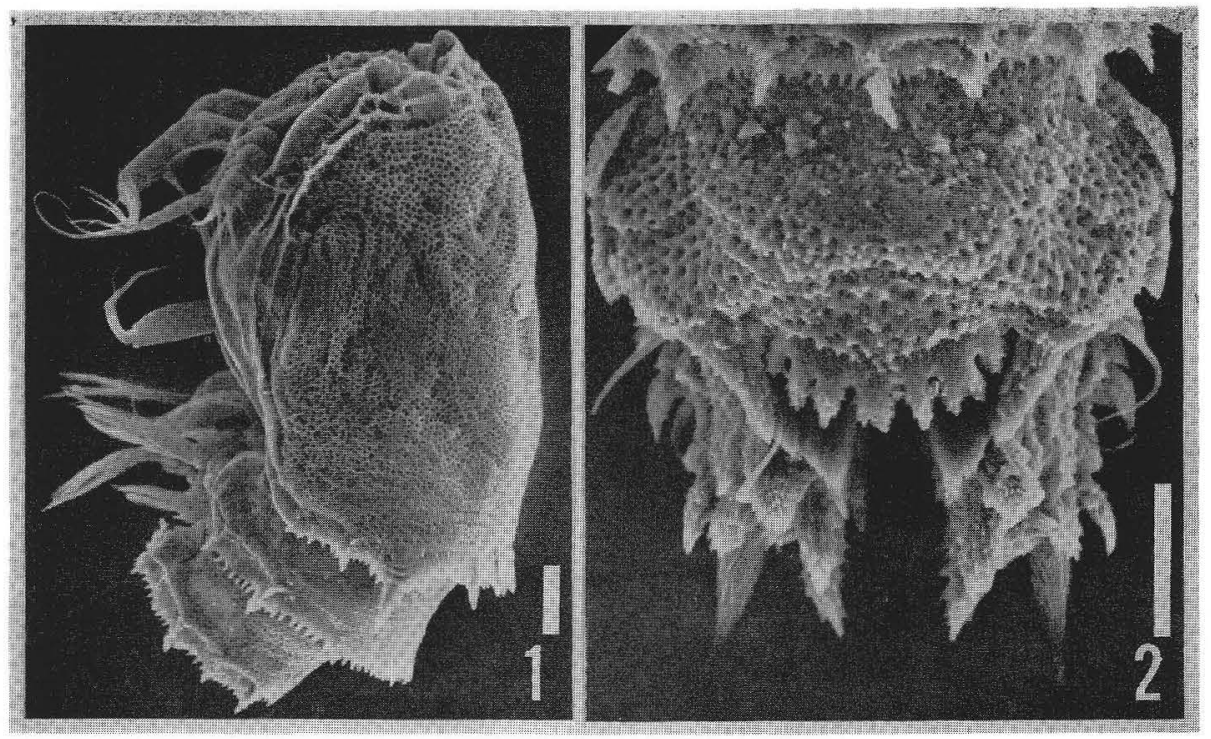

Fig. 2. Scanning electron photomicrographs of Oniscopsis inabai n. sp. 1. cephalothoracic somite of the female, lateral; 2. anal somite and furcal rami of the male, dorsal. Each scale represents $0.025 \mathrm{~mm}$.
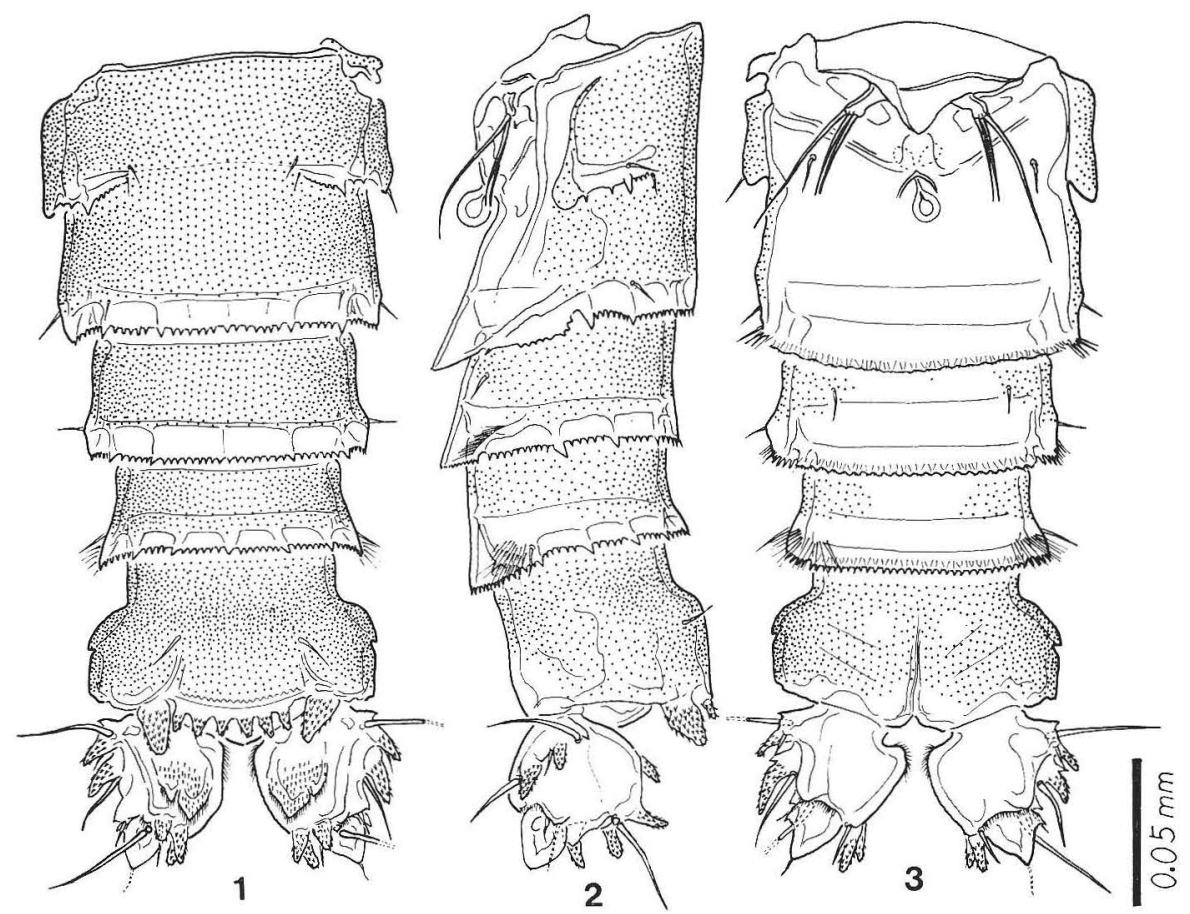

Fig. 3. Oniscopsis inabai n. sp. Female (holotype). 1. abdomen, dorsal; 2. ditto, lateral; 3. ditto, ventral (MKD-29). 
a basally geniculate seta arising near the base of a bulbiform terminal spine which bears an apical hair. Rostrum (Fig. 4, 2) defined at base, triangular in shape, about half as long as its basal width.

Antennule (Fig. 4, 2) fairly short, eight-segmented; first and third segments about 1.5 times as long as second one; an aesthetasc occurring on the cylindrical process of the third segment; apical five segments very small, of which the penultimate and

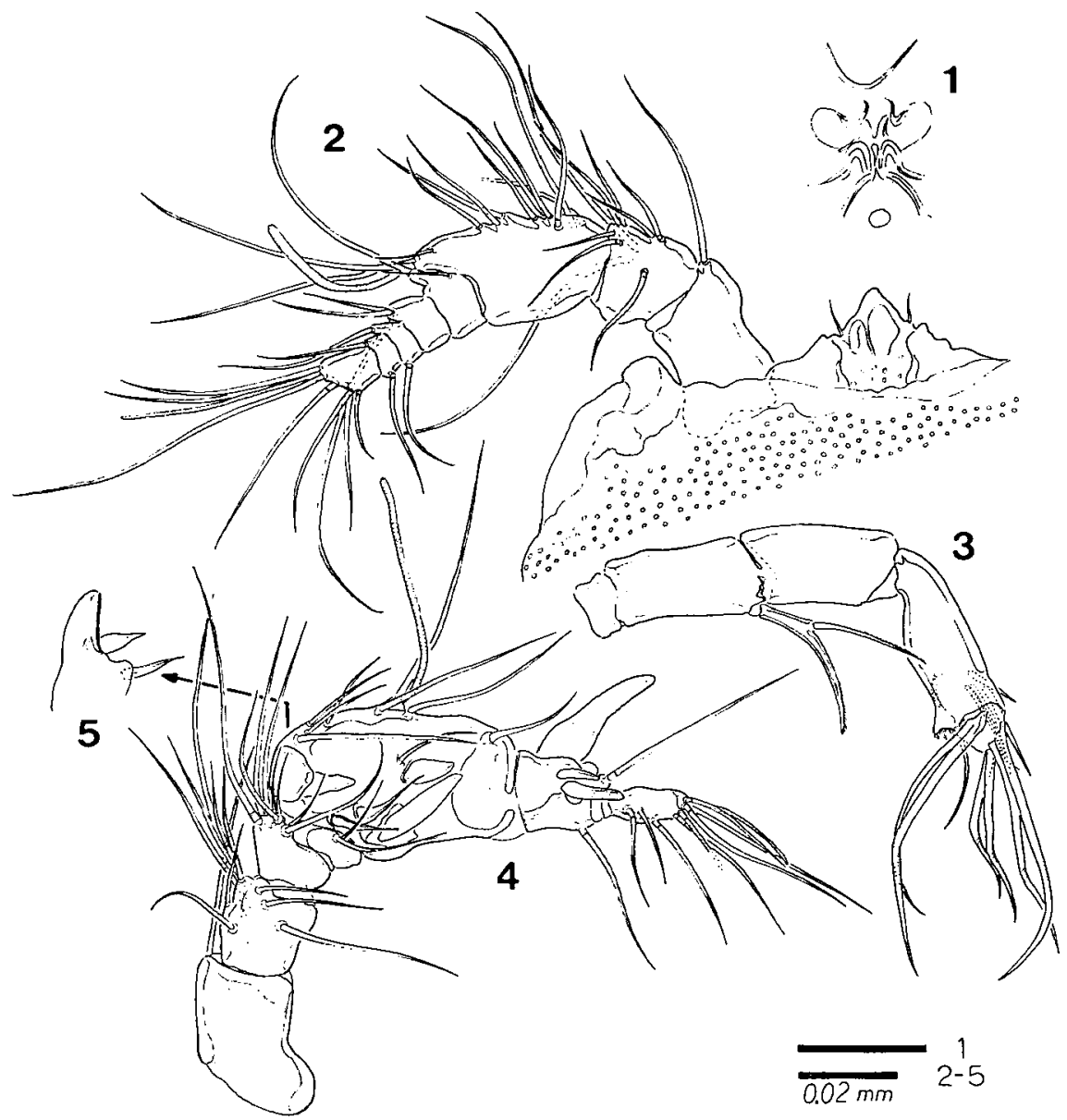

Fig. 4. Oniscopsis inabai n. sp. Female (holotype). 1. genital area (MKD-29); 2. antennule (MKD-36); 3. antenna (MKD-35). Male (paratype). 4. antennule, dorsal (MKd-91); 5. proximal projection of the fourth antennule-segment, lateral (MKd-75).

antepenultimate ones are the shortest. Antenna (Fig. 4, 3). Basis bare. Exopodite one-segmented, with two hairy apical setae, of which the thicker is almost fused with the segment at base. Endopodite partially confluent with basis on the outer face and composed of two segments; proximal segment bare, almost as long as basis; distal one about 1.5 times as long as preceding one, ornamented with two spinulose cupuliferous projections on the posterior side, and with two spines and two setae 
on about two-thirds the length of the antero-inner face; terminal end armed with one short, thin seta and six long, stout setae, five of which are geniculate. Mandible (Fig. 5, 1). Praecoxa with unidentate (?) pars incisiva, bidentate lacinia mobilis, five? serrate spines, at least four ordinary spines and one hairy seta. Coxa-basis widened distally, with three hairy setae. Exopodite two-segmented; proximal segment about three times as long as distal one, and ornamented with two inner setae, one of which is on a subterminal portion and the other near the base; the distal segment with four apical setae. Endopodite furnished with two juxtaposed inner setae halfway, and seven apical setae. Maxillula (Fig. 5, 2). Arthrite of praecoxa spinulose along the middle of dorsal edge, with seven, more or less claw-like spines and one slender spine on the inner edge, the dorsalmost one is hairy along one side; one hairy and one spinulose spine arising from the dorso-inner edge, and two hairy

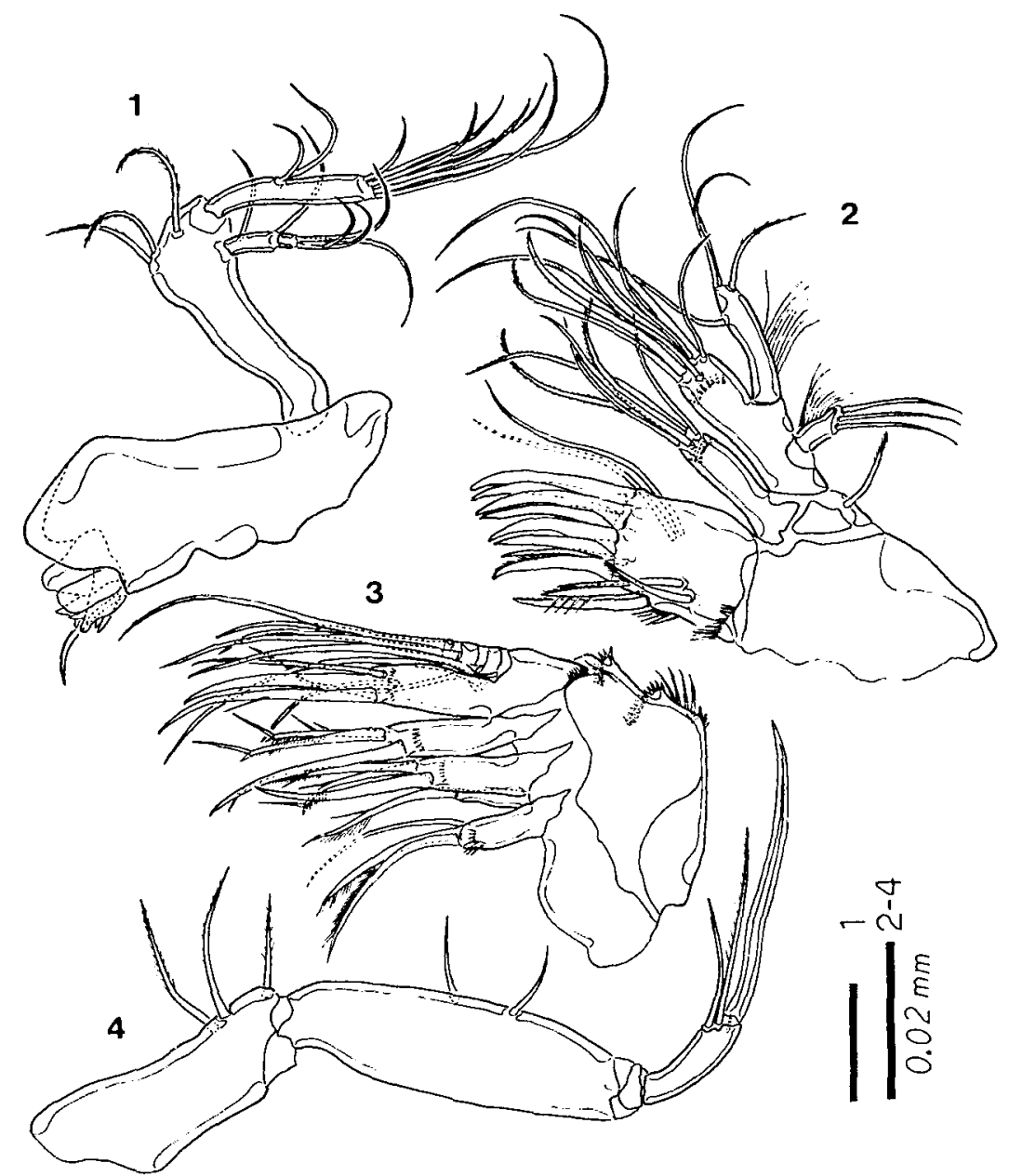

Fig. 5. Oniscopsis inabai n. sp. Female (1, 3, paratype; 2, 4, holotype). 1. mandible (MKD-6); 2. maxillula, posterior view (MKD-36); 3. maxilla (MKD-7); 4. maxillipede (MKD-34). 
setae from the posterior surface near the dorsal edge; two parallel setae on the anterior surface. Inner process of coxa bearing six apical setae, and an epipodite represented by one plumose seta. Basis armed with eight setae, two of which are geniculate. Both rami one-segmented; exopodite ornamented with many hairs along the inner edge, and three bare setae terminally; endopodite hairy along the outer edge, furnished with four setae. Maxilla (Fig. 5, 3). Syncoxa ornamented with one longitudinal and three transverse rows of spinules on the ventro-outer face, armed with four well-developed endites; first endite armed with two thicker, spinulose and one thinner, bare setae; second endite small, with one spinulose seta; both third and fourth endites with three, more or less spinulose setae, of which the dorsalmost is thickest. Basis apically armed with two claw-like setae and one slender bare seta; one seta occurring subapically on the posterior face. Endopodite threesegmented; first segment furnished with three setae and one hairlike setula; second and third ones with one and three setae, respectively. Maxillipede (Fig. 5, 4). Basis ornamented with three hairy setae, of which the distalmost is a little shorter than the others. First endopodite-segment ornamented with two short, bare setae on about the middle of inner edge; second one with one terminal claw accompanied by two slender setae, of which the longer is feebly hairy.

Leg 1 (Fig. 6, 1). Coxa extremely widened, about 2.7 times as wide as basis, forming a round large protuberance at its inner distal corner, which is posteriorly furnished with several thick spinules; a transverse row of slender spinules on the anterior face just above basis. Basis furnished with a hairy seta on both lateral edges, and with some spinules on the postero-inner face. Exopodite two-segmented; proximal segment about 1.5 times as long as distal one, with one hairy outer seta; distal one with four geniculate setae. Endopodite two-segmented; first segment almost as long as the two exopodite-segments combined, with several hairs on the middle of inner margin; second one small, almost as long as wide, armed terminally with two long thick setae. Leg 2 (Fig. 6, 2). Coxa widened, forming a round large protuberance at its inner distal corner, which is fringed with several thick spinules. Basis about 1.7 times as wide as long, excluding two triangular plates, one of which is located between both rami and the other occurs on the inner distal corner, and furnished with a bare and considerably slender, outer seta. Exopodite three-segmented; outer distal corner of first segment projecting, with a thick outer spine which is much longer than the three exopodite-segments combined; second segment ornamented with several minute spinules along the inner margin, with a long and thick outer spine; distal one with one outer spine, and one spine and one slender seta on the terminal end. Endopodite two-segmented; first segment as long as wide, ornamented with several long hairs along the inner margin, and armed with one long and thick inner spine which somewhat curves outwards; second segment about 1.7 times as long as wide, with one outer and two terminal setae, of which the innermost is sparsely hairy and the rest densely hairy. Leg 3 (Fig. 6, 3). Coxa almost the same as in leg 2, though the inner distal protrusion is less prominent. Basis almost as in the preceding leg, though a little smaller. Exopodite three-segmented; 


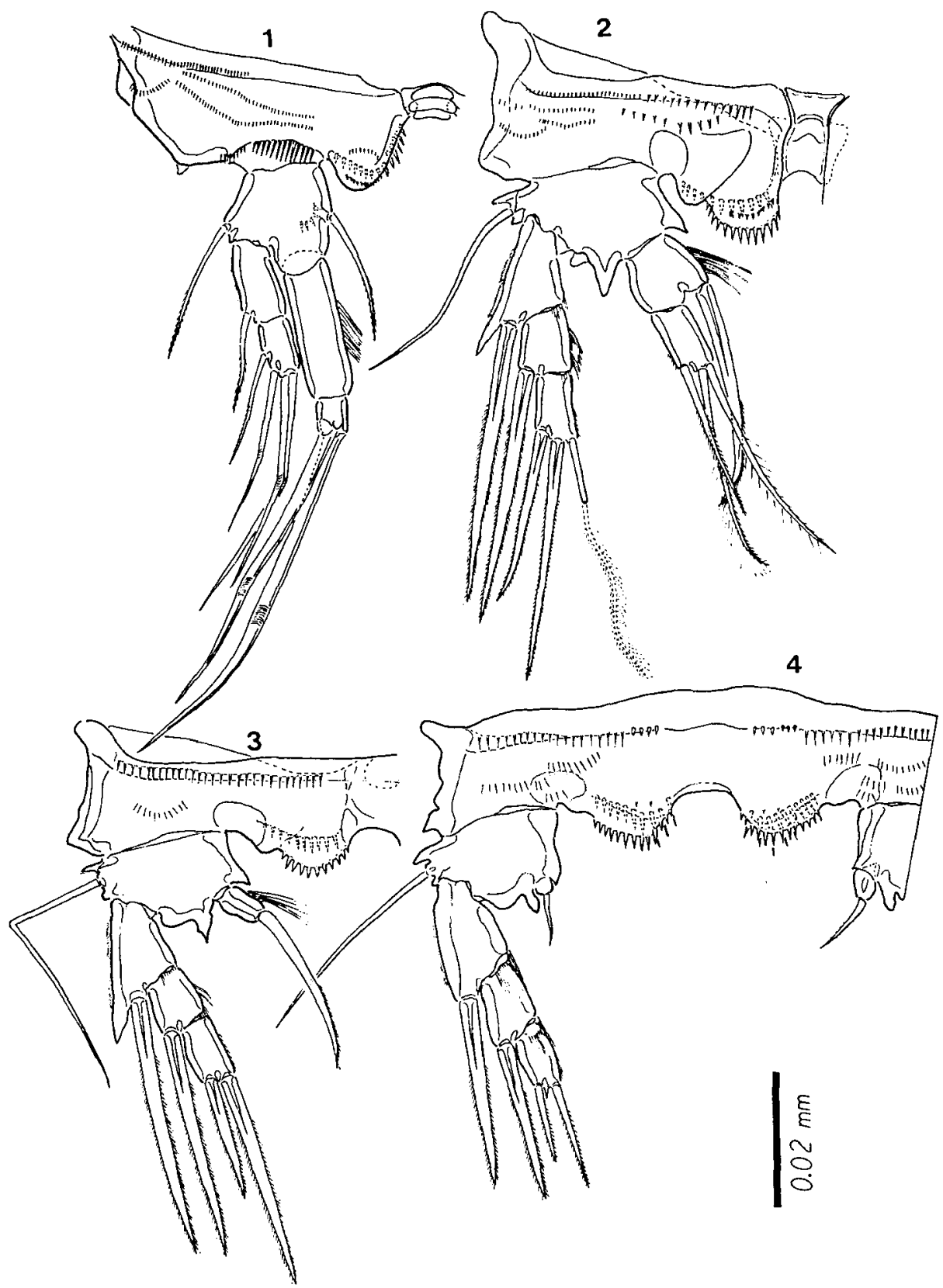

Fig. 6. Oniscopsis inabai n. sp. Female (holotype). 1. leg 1 (MKD-34); 2. leg 2 (MKD-33); 3. leg 3 (MKD-32); 4. leg 4 (MKD-31).

first segment as in leg 2; second one ornamented with a few minute spinules on the inner margin; third one with two thick spines, of which the inner is much longer than the outer. Endopodite composed of one small segment, ornamented with several long hairs on the inner edge, and armed with one thick elongate spine 
which extends beyond the distal end of the third exopodite-segment.

Leg 4 (Fig. 6, 4). A pair of coxae represented by a plate, but the inner distal protrusion as in leg 3. Basis forming a small projection between both rami. Exopodite three-segmented; first segment much larger than the succeeding ones, and bearing one stout outer spine, though lacking in an outer distal projection; distal segment furnished with two terminal slender spines, of which the inner is longer than the outer. Endopodite one-segmented, extremely degenerative, with one short seta (or spine?). Leg 5 (Fig. 8, 5) large, foliaceous, forming an egg pouch under the abdomen, ornamented with a number of punctures, and fringed with numerous hairs along the inner margin; one setula occurring at approximately four-fifths along the length of its inner margin; the middle of the hind edge recessed somewhat deeply, and densely fringed with hairs; the inner distal expansion, which probably represents the baseoendopodite, furnished with four hairy setae and one to three small projections; one hairy and five bare setae arising from the outer distal margin, rather close to the recession.

Male. Body (Fig. 1, 3) about $0.59 \mathrm{~mm}$ in length. Dorsal ornamentation of somitcs almost as in female, except that projections of the hind edge of each abdominal somite are more prominent (Fig. 7, 1-2). Second to fourth abdominal somites serrated along the ventral hind rims, ornamented with innumerable hairs as shown in Fig. 7, 3. Leg 6 armed with one spine and one seta, of which the former is thinly hairy
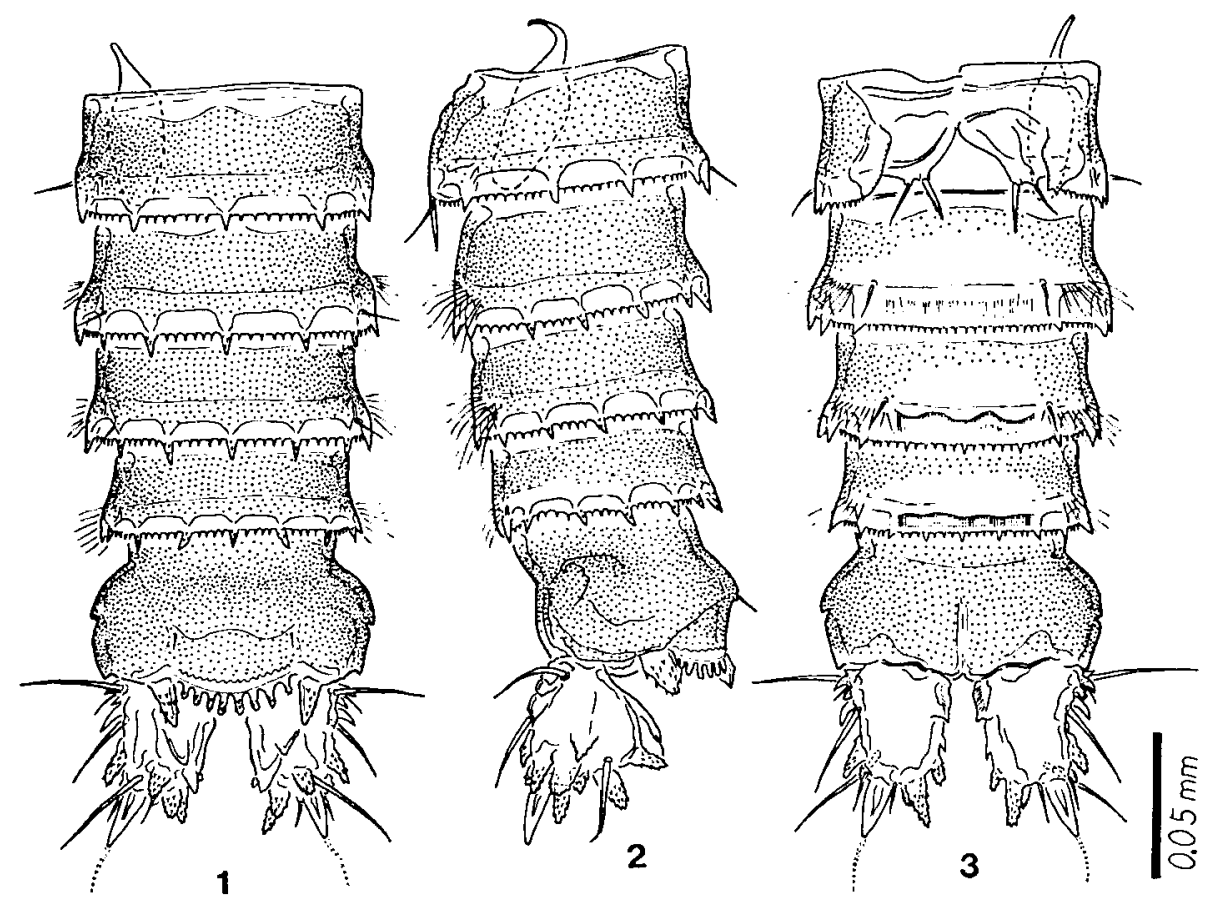

Fig. 7. Oniscopsis inabai n. sp. Male (allotype). 1. abdomen, dorsal; 2. ditto, lateral; 3. ditto, ventral ( $\mathrm{MKd}-77$ ). 
along the outer edge. Furcal ramus (Fig. 2, 2) a little longer than greatest width in contrast to the female's; terminal spine much slenderer than in female, about 2.5 times as long as greatest width. Rostrum as in female.

Antennule (Fig. 4, 4-5) haplocer; fourth segment forming a large projection near the proximal end of dorsal face, furnished with five, more or less transformed setae; penultimate segment with one large projection and two (or three) transformed setae. Antenna, oral parts and first leg almost as in female.

Leg 2 (Fig. 8, 1). Coxa, basis, exopodite and first endopodite-segment almost the same as in female. Second endopodite-segment longer than preceding one, forming a slightly salient angle on about one-third the length of the inner margin, and armed with one thick and elongate, outer subterminal spine, and with one thick elongate spine and one narrow seta terminally, all of which are bare. Leg 3 (Fig. 8, 2). Coxa, basis and exopodite almost as in female. Endopodite onesegmented, small, but somewhat wider than in female, terminating in one slender hairy seta which reaches to the distal end of the third exopodite-segment. Leg 4 (Fig. 8, 3). Basis with one outer seta which is much shorter than in female. Exopodite three-segmented; first two segments fringed with many well-developed serrate membranes along the inner distal corners of anterior faces, and armed with thick and faintly curved, outer spines; distal segment with two small spines terminally. Endopodite consisting of one extremely small segment bearing one short terminal seta. Leg 5 (Fig. 8, 4). Baseoendopodites confluent, each ornamented with some rows of spinules on the inner-proximal half of anterior surface, and strikingly serrated along the distal edge of large outer protrusion; inner expansion well-developed, ornamented with some spinules (or hairs) and one hairy small process on its outer margin, and armed with three setae of the same length, of which the innermost is bare. Exopodite about 1.8 times as long as wide, spinulose along the subproximal outer margin, bearing two outer and one terminal, bare setae, and three hairy inner setae, of which the innermost is much shorter than the adjacent longest one and with many long hairs.

Variation and abnormality. Four females and four males, other than the holotype and allotype, were dissected and thoroughly examined. In the females, their body lengths varied from $0.64 \mathrm{~mm}$ to $0.69 \mathrm{~mm}$, and in the males from $0.56 \mathrm{~mm}$ to $0.61 \mathrm{~mm}$. Extreme variation was found in the number of the marginal dentiform projections of the anal operculum: 0 (?), 4, 6 and 7 in the females, 7, 8, 8 and 8 in the males, and 5 in an undissected male. In the degree of degeneration of the endopodite, the female leg 4 is also very variable among specimens and even between both legs of a single specimen (Fig. 6, 4). In one paratypic specimen, for example, the endopodite of the right leg (MKD-24) is represented by one short seta while the left leg shows no trace of the ramus. In the same specimen, the first endopodite-segment of the left leg 2 (MKD-26) is lacking in an inner spine and, furthermore, the exopodite of the mandible (MKD-28) bears three apical setae instead of four. Another female has a somewhat abnormal left leg 4 (MKD-18), in which the third 


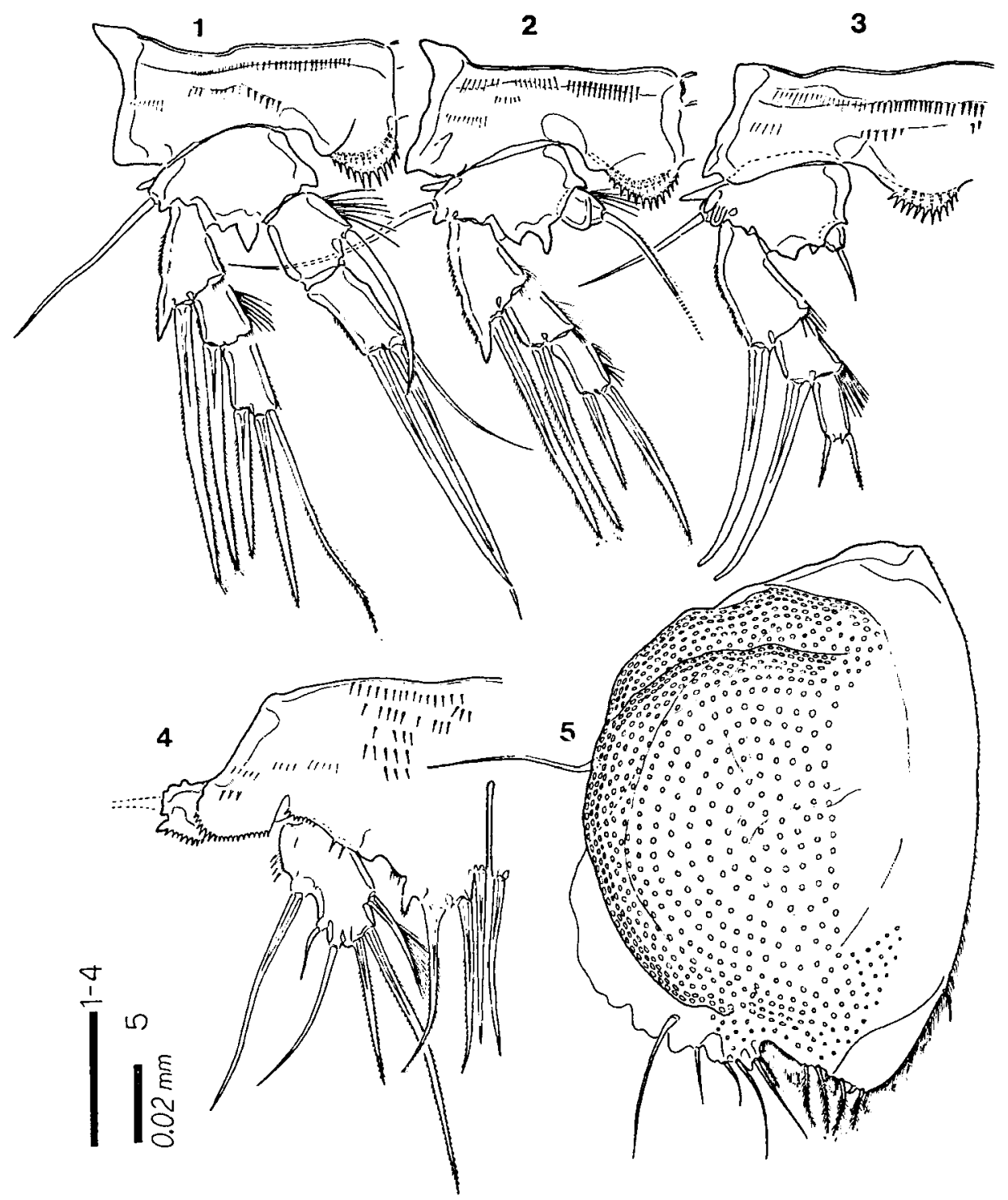

Fig. 8. Oniscopsis inabai n. sp. Male (allotype). 1. leg 2 (MKd-80);2. $\operatorname{leg} 3$ (MKd-79); 3. leg 4 (MKd-78); 4. leg 5 (MKd-78). Female (holotype). 5. leg 5 (MKD-30).

exopodite-segment bears an additional stout outer spine. In a paratypic male, the exopodite of the left leg 5 (MKd-65) has a bare subterminal inner seta, instead of a hairy one. In a separate male, the exopodite of the right leg $5(\mathrm{MKd}-71)$ is furnished with only two hairy setae without the innermost hairy seta. The right leg 6 of the same specimen (MKd-70) is armed with one thick spine, one seta, and an additional seta which is shorter than the others.

Remarks. As the present species has 2-segmented rami of leg 1, 2-segmented 
endopodite of leg 2, 1-segmented endopodite of leg 3 and leg 4, and very large, foliaceous leg 5 in the female, it is included within the genus Oniscopsis Chappuis, 1954 together with two previously known species (Lang, 1965, p. 377-378): $O$. pauliani Chappuis, 1954 from Madagascar and O. robinsoni Chappuis \& Delamare Deboutteville, 1956 from the Bahamas.

0 . pauliani resembles the present new species in the ornamentation of the thoracic legs (Table 1). However, on some characteristics, the present new species is

Table 1. Seta and spine formulae of the legs $2-4$ of the females of the genus Oniscopsis.

\begin{tabular}{|c|c|c|c|c|c|c|}
\hline & \multicolumn{2}{|c|}{ P2 } & \multicolumn{2}{|c|}{ P3 } & \multicolumn{2}{|c|}{$\mathbf{P 4}$} \\
\hline & Exp. & Enp. & Exp. & Enp. & Exp. & Enp. \\
\hline O. robinsoni & $0.0 .3(?)$ & $1.3(?)$ & 0.0 .020 & 1.1 & 0.0 .020 & 1 \\
\hline o. pauliani & $0.0 .3(?)$ & $1.3(?)$ & 0.0 .020 & 1 & 0.0 .020 & 1 \\
\hline O. inabai n. sp. & 0.0 .021 & 1.021 & 0.0 .020 & 1 & 0.0 .020 & 1 \\
\hline
\end{tabular}

(?): the total number of the setae or spines is known but their arrangements are unknown.

discernibly different from the Madagascar species. First, in the female of $O$. pauliani, the mandibular exopodite is furnished with one outer and two apical setae, and the endopodite with one seta on about one-third the length of the inner margin and four setae on the apex. In the new species, as described above, the exopodite is furnished with two inner and four apical setae, and the endopodite with two inner setae halfway and seven setae apically. Secondly, the male antennule has two stout projections on the penultimate segment in $O$. pauliani, whereas in the present species only one stout projection occurs there. Thirdly, in the Madagascar species the second endopodite-segment of the male leg 2 is armed with only two terminal spines. Finally, in both baseoendopodite and exopodite of the male leg 5 of the Madagascar species, each innermost seta is much longer than the adjacent one. In the new species, however, the three setae on the baseoendopodite are subequal in length, and the innermost seta on the exopodite is much shorter than the adjacent one (about one-third).

Type-series. Holotype: adult female. Allotype: adult male. Paratypes: four adult females and five adult males. Type-locality: intertidal zone of the sandy beach at Mukaishima Island, the Inland Sea of Japan (27-V-1981 ; Kitazima leg.).

The trivial name is coined in honor of Prof. A. Inaba of the Mukaishima Marine Biological Station, Hiroshima University.

\section{REFERENCES}

Becker, K.H. and H. Kunz, 1981. Die Stellung der Gattung Oniscopsis (CHAPPUIS) im System der Harpacticoida (Crustacea, Copepoda). Mitteil. Zool. Mus. Univ. Kiel, 1 (8): 34-37.

Chappuis, P.A., 1954. Recherches sur la faune interstitielle des sédiments marins et d'eau douce à Madagascar. IV. -Copépodes Harpacticoides psammiques de Madagascar. Mém. Inst. sci. Madagascar, sér. A, 9: 45-73.

_ and C. Delamare Deboutteville, 1956. Etudes sur la faune interstitielle des îles Bahamas 
récoltée par Mme Renaud-Debyser. I. Copépodes et Isopodes. Vie Milieu, 7 (3): 373-396.

Lang, K., 1948. Monographie der Harpacticiden. 1682 pp. 2 vols. Hakan Ohlsson, Lund.

1965. Copepoda Harpacticoidea from the Californian Pacific coast. Kungl. Svenska Vetensk. Handlinger, $10(2): 1-560$, pls. 1-6. 